\title{
The Mediator Role of Sales Force Management Capability on the Relation Between Mar- ket Orientation and Financial Performance
}

\section{O Papel Mediador da Capacidade de Gestão da Força de Vendas na Relação Entre Orien- tação para o Mercado e Desempenho Organizacional}

\author{
Graziela Perretto Rodrigues \\ Universidade Federal do Paraná - UFPR- Brasil \\ grazielarodrigues@gmail.com \\ ORCID: 0000-0002-5840-9859 \\ Cecília Souto Maior de Brito \\ Universidade Federal do Paraná - UFPR- Brasil \\ cecilia.soutomaior@gmail.com \\ ORCID: 0000-0003-3413-7331 \\ Renata Bárbara Moreno \\ Universidade Federal do Paraná - UFPR- Brasil \\ renatamorenob@gmail.com \\ ORCID: 0000-0002-8613-7264 \\ Ana Maria Machado Toaldo \\ Universidade Federal do Paraná - UFPR- Brasil \\ anatoaldo@ufpr.br \\ ORCID: 0000-0002-9578-8122 \\ Paulo Henrique Muller Prado \\ Universidade Federal do Paraná - UFPR- Brasil \\ pprado@ufpr.br \\ ORCID: 0000-0002-7351-6089 \\ Renato Zancan Marchetti \\ Pontifícia Universidade Católica do Paraná - PUCPR - Brasil \\ renato.zancan@pucpr.br \\ ORCID: 0000-0001-8784-0050
}

Submetido em 19/12/2019; Aprovado em 10/03/2020.

\section{Resumo}

Objetivo: Este estudo demonstra que a capacidade de gestão da força de vendas é um fator determinante para o desempenho financeiro quando influenciado pela orientação para o mercado. Desta forma, explora-se como cada uma das dimensões da capacidade de gestão da força de vendas (estrutura da força de vendas, gerenciamento de talentos, segmentação de clientes) contribuem na relação entre orientação para o mercado e desempenho financeiro. Metodologia: Uma pesquisa $(n=223)$ foi aplicada em empresas de Tecnologia da Informação e Comunicação (TIC) no Brasil. A modelagem de equações estruturais nos permitiu entender como as dimensões da capacidade de gestão da força de vendas influenciam a relação entre a orientação do mercado e o desempenho financeiro. Resultados: Demonstrou-se que a orientação para o mercado influencia todas as dimensões da capacidade de gestão da força de vendas (estruturação da força de vendas, gestão de talentos e segmentação de clientes), principalmente a segmentação de clientes e gestão de talentos. Além disso, demonstra-se que a relação entre orientação para o mercado e desempenho financeiro é mediada pela gestão da força de vendas. Contribuições teóricas: Este estudo contribui para a literatura de marketing ao demonstrar que a orientação para o mercado pode ser usada juntamente com a capacidade de festão de força de vendas para gerar melhor performance. Além disso, demonstra-se que para obter desempenho financeiro é necessária a 
capacidade de gestão de força de vendas. Desta forma, esta pesquisa promove uma melhor compreensão do processo pelo qual a orientação de marketing pode estar relacionada à capacidade de gestão da força de vendas, e como cada uma de suas dimensões influencia o desempenho financeiro. Contribuições práticas: Para atingir melhores resultados financeiros e vantagem competitiva, gerentes de marketing e gerentes de vendas devem colaborar na troca de informações sobre o mercado, e utilizar essas informações de maneira estratégica para segmentar e positionar suas forças de vendas. Somado a informações relacionadas a clientes, concorrentes e fatores ambientais, profissionais de marketing devem focar esforços em gerenciar melhor recursos organizacionais. As empresas devem usar as informações de mercado para melhorar o desempenho e envolver os gerentes de marketing para apoiar o investimento em vendas.

Palavras-chaves: Orientação para o mercado, capacidade de gestão da força de vendas, desempenho financeiro

\begin{abstract}
Purpose: This study demonstrates that sales force management capability (SFMC) is a driver to financial performance when influenced by marketing orientation. Wherefore, the researchers explore how each SFMC's dimension (salesforce structuring, talent management, and customer targeting) contributes on the relation between MO and financial performance. Methodology: A survey ( $n=223$ ) was applied in Information and Communication Technology (ICT) companies in Brazil. Structural equation modeling allowed us to understand how the sales management forces capability's dimensions influence the relation between market orientation and financial performance intensity. Findings: It is demonstrated that MO influences the three SFMC capability dimensions (salesforce structuring, talent management, and customer targeting), mainly customer targeting and talent management. Furthermore, it is shown that the relation between MO and financial performance is mediated by SFMC capability. Theoretical contributions: This study contributes to the marketing literature by showing that MO may be applied jointly to SFMC in order to improve performance. Furthermore, it is demonstrated that SFMC to enhance financial performance. Consequently, this study promotes a better understanding of the process in which MO may be related to SFMC, and how each specific dimension of SFMC influences financial performance. Practical contributions: Marketing managers and sales managers should sharing information about the market to achieve better financial results and competitive advantage. Also, practitioners should use market information strategically to segmenting and positioning sales force. In addition to customers, competitors, and environmental forces, petitioners should make an effort to manage their organizational resources better. Firms should use market information to improve performance and engage marketing managers to support sales investment.
\end{abstract}

Keywords: Market orientation, sales force management capability, financial performance

\title{
1. Introduction
}

Market orientation (MO) has been investigated in marketing literature mainly because of its contribution to organizational performance (Kohli \& Jaworski, 1990; Narver \& Slater, 1990; Thornton, Henneberg \& Naudé, 2015; Guo, Wang Hao \& Saran, 2018). The core concept of MO is to seek information about customers and competitors, and other environmental forces, to make organizational decisions more appropriate (Kohli \& Jaworski, 1990; Guo et al., 2018; Mamun, Mohiuddin, Fazal \& Ahmad, 2018). However, despite many studies regarding MO, there is no complete understanding of its influence on financial performance (FP) (Guo et al., 2018; Mamun et al., 2018) For this reason, it is necessary to understand this process in a more detailed way.

On the one hand, some studies suggest a positive relation between $\mathrm{MO}$ and organizational performance (Guo et al., 2018; Mamun et al., 2018). Similarly, the development of marketing capabilities may enhance this relation, since by shaping firm's strengths, they become more competitive (Morgan, Vorhies, \& Mason, 2009). On the other hand, although there are few studies relating MO and marketing capabilities, it is still a latent need to investigate the relation between MO and specific capabilities, such as sales capability (Smirnova, Naudé, Henneberg, Mouzas, \& Kouchtch, 2011; Morgan, 2012; Ngo \& O'Cass, 2012). Therefore, to contribute to filling up this gap, we propose that MO generates FP through sales force management capability (SFMC).

Several studies focus on the sales team's ability or on the salesperson, but little is known about 
how the managerial process happens to achieve financial goals (Wang and Miao, 2015; Kumar, Sunder, \& Leone, 2014; Cron, Baldauf, Leigh, \& Grossenbacher, 2014). Since Guenzi, Sajtos, and Troilo (2016) present a distinct construct of personal selling capability, unlike other authors (i.e., Krush, Agnihotri, \& Trainor, 2013; Vorhies \& Morgan, 2005), this study uses the Guenzi et al. (2016) SFMC's approach to investigate the influence of SFMC on the relation between MO and financial performance. By doing so, the present research aims to contribute with the literature, building up with the few recent studies focused on SFMC (Krush et al., 2013; Siahtiri, O'Cass, \& Ngo, 2014, Guenzi et al., 2016). Thus, the main purpose of this study is to demonstrate that sales force management capability is a driver to financial performance when influenced by marketing orientation.

Furthermore, the SFMC investigation allows a broad understanding of the organization's ability to deal with the sales area (Guenzi et al., 2016), which may assist managers in their decisions regarding resource allocation. However, although sales are everyday activities, there is still little understanding of how to manage the sales force to achieve performance (Guenzi et al., 2016), mainly when it regards to financial results (Guo et al., 2018; Mamun et al., 2018). Thus, this study also aims to verify the mediating role of SFMC in the relation between MO and FP.

By doing so, in a theoretical view, this study helps to understand organizational resources combination, the effects that MO and SFMC have on FP. Although MO is an explored subject, the understanding of its impact on FP is relevant in the marketing literature (Guo et al., 2018; Mamun et al., 2018). A deep understanding of how SFMC helps to explain the relationship between MO and FP. Furthermore, the contribution of each dimension of SFMC ((salesforce structuring, talent management, and customer targeting) is provided. For practitioners, this research contributes to a better understanding of the allocation of resources to obtain superior performance through the management activities of the sales area, enabling the development of more effective sales strategies. MO is crucial to achieving better results in the B2B market when used to develop sales management, even is a competitive sector as ICT.

To accomplish the proposed goals, the present research uses data collected from the Information and Communication Technology Sector (ICT), a competitive sector that depends on sales team performance (BRASSCOM, 2016). ICT companies develop hardware, software, and services solutions, which are incorporated by companies from all other sectors of the economy (BRASSCOM, 2013). In this B2B context, studies about MO and sales capability are relevant to generate long-term relationships (Weitz \& Bradford, 1999; Chang, 2014; Guo et al., 2018). Also, B2B marketers focus on customer relationships, which makes the role of sales force management a priority (Baldauf, Cravens, \& Piercy, 2001). The following sections structure the present study: Conceptual framework, Method, Results, and General Discussion.

\section{Conceptual Framework}

\subsection{Market Orientation on the development of Sales Force Management Capability}

Market orientation (MO) is a strategic orientation related to the development of marketing theory, which leads to a positive result on organizational performance in short and long terms (Ngo \& O'Cass, 2012). MO can fit all companies' types, as well as customers (Kumar, Jones, Venkatesan, \& Leone, 2011; Liao, Chang, Wu, \& Katrichis, 2011). Several authors present related MO definitions, all to provide a better understanding of organizational results in a strategic intelligence perspective (Deshpandé, 1999; Kohli \& Jaworski, 1990; Narver \& Slater, 1990).

Based on these arguments, Kohli and Jaworski (1990) showed that all companies are market-oriented at some level because different resources are used to attract customers and reach a better performance (Kirca, Jayachandran \& Bearde, 2005). Additionally, some studies have shown how MO influences specific dimensions of performance, demonstrating that MO promotes positive results on revenues (Ngo \& O'Cass, 2012; Guo et al., 2018; Mamun et al., 2018).

However, MO leads to the development of different organizational abilities and activities (Baker \& Sinkula, 1999). Specifically, Narver and Slater (1990) explore how activities of acquisition, dissemination of information, and customer value coordination are behavioral dimensions of organizational culture. High-level MO companies stimulate the improvement of capabilities that make the relations between customers' expectations and delivered value more congruent (Day, 1994). These activities in- 
volve customers, competitors, and inter-functional coordination that have the potential to improve capabilities and financial results (Siahtiri et al., 2014; Narver \& Slater, 1990). Mohiuddin Babu, Jayawardhena, and Dey (2019) verified the influence of the dimensions of MO into customer-based performance and suggested that this orientation should be explored with other resources, as SFMC and FP.

Whereas many marketing capabilities are present in companies, managerial actions and decisions should be strategically oriented to the development of a body of specific capabilities. In this way, the sales force is a strategic oriented marketing capability (Morgan et al., 2009) essential to marketing relationship development (Homburg, Vomberg, Enke, \& Grimm, 2015), involving managerial and individual skills (Guenzi et al., 2016).

Sales capabilities have been built from strategic choice's reflection on sales department's activities and involve constant customer contact, business transactions, market diagnosis, and responses, as well as credibility and trust construction (Day, 1994; Baldauf et al., 2001). MO, from a cultural perspective, is an antecedent of these capabilities and guides its development since market intelligence is the core of its activities (Morgan et al., 2009).

Previous studies have shown that MO influences marketing capabilities (Smirnova et al., 2011; Ngo \& O'Cass, 2012). Among a range of organizational capabilities that MO helps to develop, sales capability probably is one of them (Guenzi et al., 2016, Mohiuddin Babu et al., 2019). Marketing and sales activities are complementary and vital to achieving performance (Homburg et al., 2015). Additionally, there is a discussion to explore each marketing capability in-depth (Morgan, 2012). So, it should be emphasized in this study the roles that each of the SFMC dimensions, such as salesforce structuring (SFS), talent management (TM), and customer targeting (CT) (Guenzi et al., 2016), are investigated on the relation between MO and FP. The authors test only the relationship between SFS and profit performance, concluding that few studies explore the impact of sales capabilities only on one performance indicator. Since more studies are necessary to explore SFS capability and different performance types, the present research complements the findings by exploring the impact of MO, SFMC, and FP.

MO influences marketing capabilities (Smirnova et al., 2011; Ngo \& O'Cass, 2012) and should be explored with other resources (Mohiuddin Babu et al., 2019), as SFMC and its dimensions. MO generates market information, helping to structure the salesforce in companies. SFC involves different decisions such as salespeople quantity, product variety assigned to each one, and the organization of this salesforce to act as a team (Rangaswamy, Sinha \& Zoltners, 1990; Zoltners, Sinha, \& Lorimer, 2008). Therefore, we propose:

H1a: Market orientation (MO) positively influences sales force structuring (SFS).

Similarly, the manager is responsible for the leadership, motivation, and communication that influences the sales team behavior, and how salespeople persuade customers (Baldauf et al., 2001). One of the challenges of sales force management is to ensure talent's attraction from management and development to the final team results, that is, to verify how this salesforce helps to achieve the planned results (Zoltners et al., 2008). In summary, it is necessary to use market information to manage sales force talents to attend customer expectations. It is proposed that:

H1b: Market orientation (MO) positively influences talent management (TM).

In the same way, the market information is used to better target customer segmentation. In addition, structuring the sales force and managing talent makes necessary resource allocation and sales efforts. The manager develops an ability to segment customers, targeting customers in the right way, and selecting the appropriate selling model for each customer. That is, segment the customers and act on it with the sales force appropriately (Guenzi et al., 2016). Thus, we propose:

H1c: Market orientation (MO) positively influences customer targeting (CT).

\subsection{Sales Force Management Capability and Financial Performance}

Performance is a complex of results that can be evaluated in organizational and financial shapes. Organizational performance is composed of direct sales results, including volume, market share, and other financial indexes (Baudalf et al., 2001). The sales team management can directly affect firm's financial results (Cravens, Ingram, LaForge, \& Young, 1993; Zoltners et al., 2008).

Financial performance (FP) is the achievement of a short-term object due to relationship actions, 
mostly performed by salespeople work (Homburg et al., 2015). Salespeople are part of the sales force, and organizational abilities aim to manage this team to have better performance (Baudalf et al., 2001).

SFMC is a fundamental capability in the complex of organizational performance efforts. This capability is related to management activities. According to Guenzi et al. (2016), SFMC is composed of three dimensions - SFS, TM, and CT. Also, several related studies have shown that sales capabilities contribute to some degree to financial results (Vorhies \& Morgan, 2005; Morgan et al., 2009). However, these studies are generic and do not demonstrate the contribution of each dimension.

Similarly, Krush et al. (2013) explore sales capability and how it influences sensemaking. That is, this resource helps forms to build market knowledge. Siahtiri et al. (2014) explore the impact of sales and marketing capabilities on customer-centric performance. These studies about sales capabilities do not explore financial results and do not use a managerial capability as proposed in this work.

FP is short-term and also reflects management work (Homburg et al., 2015). The manager aims to ensure the performance of the sales team to achieve the objectives planned (Zoltners et al., 2008). By structuring the sales force appropriately, there are more significant conditions for the development of the salesperson activities in the market (Cravens et al., 1993; Zoltners et al., 2008). In this way, there are probably more financial results in the short-term (Homburg et al., 2015; Guenzi et al., 2016). Thus: H2a: Salesforce structuring (SFS) positively influences financial performance (FP).

Likewise, by effectively managing talent, the team is more prepared to serve clients in a segmented and in a more assertive way (Baudalf et al., 2001; Guenzi et al., 2016), which probably leaves the most appropriate solutions to clients. It thus tends to generate better financial performance, as a result: $\mathrm{H} 2 \mathrm{~b}$ : Talent management (CT) positively influences financial performance (FP).

Furthermore, sales force need to develop their activities according to CT to generate financial results (Homburg et al., 2015), this CT includes the efforts to sell products and services on the market according to each customer (Guenzi et al., 2016). We proposed:

\section{H2c: Customer targeting (CT) positively influences financial performance (FP).}

\subsection{The mediator role of sales force management capability and its dimensions}

There is a general belief that MO generates performance, including financial results. However, some studies demonstrated that contextual factors prove this assumption not significant (Colton, Roth, \& Bearden, 2010; Simirnova et al., 2011; Pekovic \& Rolland, 2016; Guo et al., 2018). Additionaly, two meta-analyses argue that the relation between MO and FP is weak (Matear, Osborne, Garrett, \& Gray, 2002; Kirca et al., 2005).

One explanation is that MO is one strategic orientation focused on customers, competitors, and actions coordinated internally within the company. The results of this strategic orientation are market information (Narver \& Slater, 1990). This market information is used in long-term relationships with customers. Meanwhile, FP reflects short-term actions (Homburg et al., 2015). We propose that to achieve this result in short-term, MO and SFMC work together.

MO facilitates the development of marketing capabilities. Marketing mix activities, which are marketing capabilities, are influenced positively by different performance indexes, such as new product development, customer, and financial ones (Shin \& Aiken, 2012; Ngo \& O'Cass, 2012). While marketing capabilities are abilities developed from a strategic orientation, both capabilities and strategic orientation contribute to organizational performance (Morgan et al., 2009). By these relations, one can note that SFMC, as a marketing capability, also has a mediator role on the relationship between MO and performance (Smirnova et al., 2011; Murray, Gao, \& Kotabe, 2011; Shin \& Aiken, 2012; Ngo \& O'Cass, 2012).

MO leads companies to have more customers and competitor's information, thus improving performance (Guo et al., 2018). When managing this information, SFMC presents activities to potentialize the firm customer value proposal (Narver \& Slater, 1990; Guenzi et al., 2016). Especially customer information has a massive impact on salespeople activity (Rapp, Agnihotri, \& Baker, 2011). More marketoriented companies tend to achieve higher performance, including financial results and even if they use MO as a resource to develop sales abilities, they can enhance the effect on performance (Guenzi et al., 2016).

For these reasons, we propose that SFMC dimensions mediate the relation between MO and FP. 
Indeed, SFS use market information to organize salesperson activities, and with this management, SFS benefit financial result by ensuring sales force work (Zoltners et al., 2008). Thus, we propose:

H3a: Salesforce structuring (SFS) mediates the relation between market orientation (MO) and financial performance (FP).

In the same manner, TM is influenced by market information, and with this market intelligence, skills are developed to obtain better FP. In other words, the market information is used to prepare the sales team, and with greater capability, this teamwork in a more effective way (Guenzi et al., 2016). One well-prepared team is likely to produce greater results in the short term, that is, produce FP:

H3b: Talent management (TM) mediates the relation between market orientation (MO) and financial performance (FP).

Lastly, the members of the sales force need to make efforts to sell products and services on the market (Guenzi et al., 2016), and for CT it is essential to market information. The manager uses this information to do better customer segmentation, optimizing sales resources, and thus obtaining better financial results:

H3c: Customer targeting (CT) mediates the relation between market orientation (MO) and financial performance (FP).

Figure 1 presents the theoretical model that will be investigated, exposing the constructs and the relations between them. As described in hypotheses, MO influences FP when mediated by SFMC, as explained earlier through SFS, TM, and CT.

Figure 1. Theoretical Model

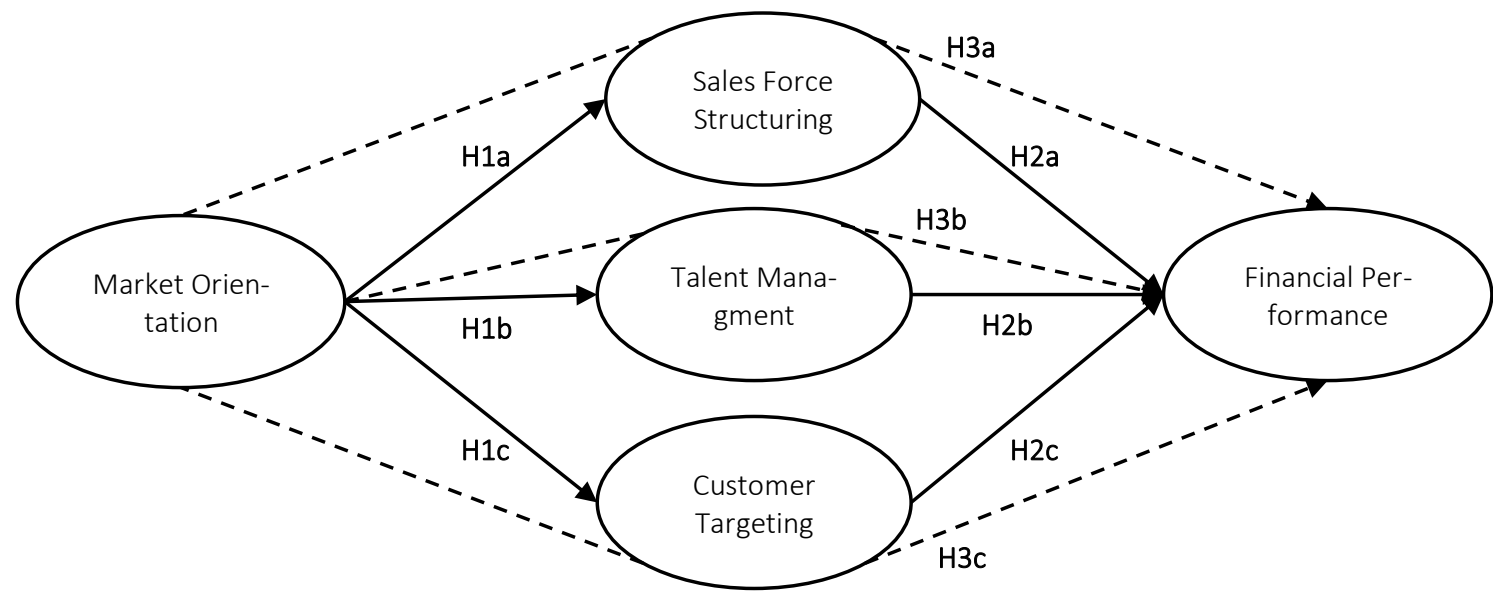

Source: The authors (2017).

\section{Methodology}

\subsection{Survey and data collection}

This study employs a correlational design to examine the proposed relationships among MO, SFMC, and FP. The survey instrument was designed using adaptations of validated scales present on literature. All statements were indicated by participants in a 10 points Likert anchored by 1 - Completely disagree to 10 - Completely agree.

The questionnaire was composed of 32 items. MO was measured using Narver and Slater (1990)'s scale and the cultural approach was used to marketing capabilities (Morgan et al., 2009). SFMC was measured using Guenzi et al. (2016)'s scale, which presents three dimensions with eight indicators (SFS, TM, and CT). FP was measured using Cruz-González et al. (2015)'s instrument, adapted from Venkatraman (1989) with six indicators and Guenzi et al. (2016)'s scales, with three items. The most common indicators for measuring sales results are financial and market parameters (Baldauf et al., 2001). Financial performance is composed of economic indicators (Venkatraman \& Ramanujam, 1986), in addition to market indicators, such as revenue growth and market share (Guenzi et al., 2016). The questionnaire 
was validated by a salesperson and two marketing/sales managers, who presented no difficulty in understanding it.

\subsection{Sample}

To test the proposed hypotheses, a survey $(n=223)$ was performed in the B2B context. Software and technology companies (ICT) from the South and Southeast of Brazil were used, which represent $75 \%$ of the Brazilian technological market (ABES, 2015). Once software services and solutions are used in almost all economic sectors (BRASSCOM, 2013), these companies need to develop long-term relationships and sales activities (Chang, 2014; Weitz \& Bradford, 1999).

Companies were selected in several ways during three months: First, at a scheduled meeting at ICT's associations from the South of Brazil. Second, at two of the major annual Brazilian ICT's conferences, E-Commerce Brazil and 18음 International Free Software Forum, resulting in 166 cases. Finally, by a selection made by Linkedin and telephone, the survey was sent to CEOs, marketing managers, commercial managers, and salespeople, resulting in 86 cases. The final sample represents a return rate of 31\%. Twenty-five of the collected cases were discarded because they differ from the expected profile. Four cases were outliers and eliminated after data treatment in the SPSS software. The final sample was 223.

For data treatment, the Kolmogorov-Smirnov test was performed. It presents $p$-value $>0.05$, that is, the data are non-normal. Because of that, we used the SmartPLS® 3.2.7. PLS-SEM software. This software is indicated for a sample with non-normal data, and its increasing use in the Marketing area demonstrates its robustness and applicability in the models in the area (Ringle; Da Silva; Bido, 2014).

To test hypotheses $\mathrm{H} 1 \mathrm{a}, \mathrm{H} 1 \mathrm{~b}, \mathrm{H} 1 \mathrm{c}, \mathrm{H} 2 \mathrm{a}, \mathrm{H} 2 \mathrm{~b}$, and $\mathrm{H} 2 \mathrm{c}$, the data were analyzed using the partial least squares-structural equation modeling approach, a nonparametric method that minimizes the amount of unexplained variance (Hair et al., 2014).

The SPSS software version 22 was employed to analyze the descriptive statistics and demographics of this study. Regarding the size, the sample is composed of micro (29\%), small (30\%), medium (13\%), and large (28\%) size companies. Software developing and solutions $(78,5 \%)$ and technologies, information, and communications providers services (21,5\%) comprehend the companies' fields. According to geographic localization, $57,4 \%$ of the companies are from the South of Brazil and $42,6 \%$ are from the Southeast.

Respondents were $76 \%$ male. Regarding the position, $42 \%$ were managers, $37 \%$ owners, and $21 \%$ salespeople. To prevent common method bias, participants were assured that their identities would remain entirely anonymous.

\section{Results}

\subsection{Convergent and discriminant validity}

After performing Exploratory Factorial Analysis, measured items were grouped in index items to each construct. Results were satisfactory with regarding Composite Reliability (CR > .70) and reliability for the items within this measurement scales (CA > .852).

Table 1. Summary of descriptive statistics and reliability and validity of measurement model

\begin{tabular}{|l|c|c|c|c|c|c|c|c|}
\hline Constructs & $\mathbf{N}$ & Mean & $\begin{array}{c}\text { Standard } \\
\text { deviation }\end{array}$ & $\begin{array}{c}\text { Cronbach } \\
\text { alpha } \\
\text { (CA) }\end{array}$ & $\begin{array}{c}\text { Composite } \\
\text { Reliability } \\
\text { (CR) }\end{array}$ & $\mathbf{R}^{\mathbf{2}}$ & $\begin{array}{c}\text { Average Va- } \\
\text { riance Ex- } \\
\text { tracted } \\
\text { (AVE) }\end{array}$ & $\begin{array}{c}\text { Variance } \\
\text { inflation } \\
\text { factor } \\
\text { (VIF) }\end{array}$ \\
\hline MO & 223 & 8.11 & 1.35 & .912 & .926 & - & .511 & 1.000 \\
\hline SFS & 223 & 7.23 & 2.33 & .841 & .929 & .351 & .814 & 1.617 \\
\hline TM & 223 & 7.34 & 2.03 & .852 & .910 & .382 & .772 & 2.553 \\
\hline CT & 223 & 7.90 & 1.77 & .884 & .926 & .304 & .863 & 2.446 \\
\hline FP & 223 & 7.50 & 1.85 & .960 & .966 & .536 & .750 & - \\
\hline
\end{tabular}

Source: The authors (2017), from primary data.

Note. MO - Market Orientation, SFS - Sales Force Structuring, TM - Talent Management, CT - Customer Targeting, FP - Financial Performance. 
The coefficients of determination $\mathrm{R}^{2}$ (explained variance) were all higher than 0.30 , which represents a large effect for social and behavioral sciences (Cohen, 1988). Regarding discriminant validity, all the values of average variance extracted (AVE) were higher than 0.50 . The discriminant validity of each item was guaranteed by the presence of a value greater in the construct than the mean variances extracted (AVE) of the other constructs of the model (Fornell and Larcker, 1981, Hair et al., 2014), as presented in Table 2.

Table2. Discriminant Validity

\begin{tabular}{|l|l|l|l|l|l|}
\hline & FP & SFS & TM & MO & CT \\
\hline FP & $\mathbf{0 , 8 7 2}$ & & & & \\
\hline SFS & 0,629 & $\mathbf{0 , 9 0 2}$ & & & \\
\hline TM & 0,658 & 0,590 & $\mathbf{0 , 8 7 9}$ & & \\
\hline MO & 0,486 & 0,595 & 0,620 & $\mathbf{0 , 7 1 5}$ & \\
\hline CT & 0,631 & 0,565 & 0,754 & 0,554 & $\mathbf{0 , 9 2 9}$ \\
\hline
\end{tabular}

Source: The authors (2017), from primary data.

Note. MO - Market Orientation, SFS - Sales Force Structuring, TM - Talent Management, CT - Customer Targeting, FP - Financial Performance.

In brief, the model present convergent and discriminant validity. Also, the model did not present common methods bias (46.2\%), because the value is less than $50 \%$ according to Harman one-factor test. As all variables in the model were collected at the same time and with the same instrument, this test shows if the variation can be explained by a single factor, which would cause a bias (Lowry \& Gaskin, 2014).

\subsection{Hypothesis testing}

Results show that MO influences SFS $(\beta=0.59$, $p$-value $=.000)$, TM $(\beta=0.562$, $p$-value $=.000)$, and CT $(\beta=0.55$, p-value $=.000)$, confirming H1a, H1b, and H1c. The hypotheses test shows that MO influences each SFMC dimension (H1a, H1b, and H1c). This fact reinforces marketing literature by demonstrating that MO developed marketing capabilities (Vorhies \& Morgan, 2005; Morgan et al., 2009). However, this research brings new knowledge presenting that the market information has an impact on all dimensions of SFMC.

Also, FP is influenced by SFS $(\beta=0.32$, p-value $=.000)$, TM $(\beta=0.29$, $p$-value $=.000)$, and CT $(\beta=$ 0.22 , p-value $=.000$ ), confirming H2a, H2b e H2c (Table 3 ). This fact demonstrated that the three dimensions of SFMC contribute to FP, expanding knowledge in the area, which had only the impact of SFS in profit performance (Guenzi et al., 2016).

Table 3. Hypothesis Test - Direct Effects

\begin{tabular}{c|c|c|c|c}
\hline Hypothesis & Path coefficient $(\boldsymbol{\beta})$ & t-Value & p-value & Result \\
\hline H1a: MO $\rightarrow$ SFS & 0.595 & 11.879 & 0.000 & Supported \\
\hline H1b: MO $\rightarrow$ TM & 0.62 & 14.079 & 0.000 & Supported \\
\hline H1c: MO $\rightarrow$ CT & 0.554 & 11.594 & 0.000 & Supported \\
\hline H2a: SFS $\rightarrow$ FP & 0.329 & 4.624 & 0.000 & Supported \\
\hline H2b: TM $\rightarrow$ FP & 0.296 & 3.091 & 0.002 & Supported \\
\hline H2c: CT $\rightarrow$ FP & 0.222 & 2.427 & 0.015 & Supported \\
\hline
\end{tabular}

Source: The authors (2017), from primary data.

Note. MO - Market Orientation, SFS - Sales Force Structuring, TM - Talent Management, CT - Customer Targeting, FP - Financial Performance. 
To test the hypotheses 3a, 3b and 3c, significant confidence intervals were applied (95\%), using bootstrap $(n=5000)$ method; specifically, the $\mathrm{R}$ software was used. For small samples, the bootstrap simulation technique shows more reliable results in terms of statistical power and dispenses with the need for normal data distribution (Hayes, 2013). The significant effect is indicated by the absence of signal exchange between the upper and lower limits of the confidence interval.

Mediation results showed significant effects. The relation between MO and FP is mediated by SFS $(\beta=.178$, C.I. $=.0047$ to .325 , p-value $\leq .05)$, by TM $(\beta=.258$, C.I. $=.0082$ to .436 , $p$-value $\leq .05)$, and by CT $(\beta=.269$, C.I. $=.15$ to .416 , p-value $\leq .05)$, confirming H3a, H3b and H3c (Table 4). These findings demonstrated that SFMC is a mediator between MO and FP, and reinforced studies that explore MO as a mediator between marketing capabilities and organizational performance (Smirnova et al., 2011; Murray et al., 2011; Shin \& Aiken, 2012; Ngo \& O'Cass, 2012).

Table 4. Hypothesis Test - Indirect Effects

\begin{tabular}{l|c|c|c|c|c|c}
\hline Hypothesis & $\begin{array}{c}\text { Path coefficient } \\
(\boldsymbol{\beta})\end{array}$ & IC Inferior & IC Superior & error & p-value & Result \\
\hline H3a: MO $\rightarrow$ SFS $\rightarrow$ FP & $\mathbf{. 1 7 8}$ & .0047 & .325 & .07 & 0.011 & Supported \\
\hline H3b: MO $\rightarrow$ TM $\rightarrow$ FP &. $\mathbf{2 5 8}$ & .082 & .436 & .09 & 0.004 & Supported \\
\hline H3c: MO $\rightarrow$ CT $\rightarrow$ FP &. $\mathbf{2 6 9}$ & .15 & .416 & .069 & 0.000 & Supported \\
\hline
\end{tabular}

Source: The authors (2017), from primary data.

Note. MO - Market Orientation, SFS - Sales Force Structuring, TM - Talent Management, CT - Customer Targeting, FP - Financial Performance.

\section{General Discussion}

This research is the first that presented that MO has an impact on all dimensions of SFMC. Also, it is the first to demonstrate that TM (H2a) and SFS (H1a) has a greater impact when compared to CT (H3a) when exploring one marketing capability in specific (Morgan, 2012). These findings contribute to marketing literature showing that MO can be used with other resources to generate performance (Mohiuddin Babu et al., 2019).

In addition, this research presents that SFS (H2a) and TM (H2a) present more effect on FP when compared to CT (H3b). One explanation is that the market information developed capabilities or operational activities, that is, the actions to manage team organization, including structure and talent. Therefore, the market segmentation is strategic and responsible to allocate the talents in each segment posteriorly. That is, SFS and TM probably are activities that reflect the strategy in results since the sales manager needs to guarantee sales force performance (Zoltners et al., 2008). In brief, SFS and TM are two dimensions that contribute to FP, but CT contributes less when analyzed separately. In summary, despite some differences, the three dimensions contribute to FP. These findings demonstrate that it is not only SFS that can generate profit performance as a previous study (Guenzi et al., 2016).

This analysis is reinforced with the results of SFMC mediation between OM and FP (H3a, H3b, and $\mathrm{H} 3 \mathrm{c}$ ). The three mediations together account for $70 \%$ of the effect of OM on FP. Instead, when we analyze the three mediations at the same time, CT has a greater impact on FP (H3c) when compared to SFS (H3a) and TM (H3b).

In conclusion, the research results show that market knowledge, as well as strategic orientation, and sales capability work together to achieve financial results.

\subsection{Theoretical Implications}

The main goal of this study is to contribute to a better understanding of the process by which MO can be related to SFMC and which specific variable dimension has the greatest effect on FP. Regarding this goal and the author's findings, this research has three main contributions to the extant theory about marketing strategies and sales management.

First, results showed that SFMC plays the role of mediation on the relationship between MO and $\mathrm{FP}$, corroborating with studies that confirm the mediating role of marketing capabilities in this relationship (Smirnova et al., 2011; Murray et al., 2011; Shin \& Aiken, 2012; Ngo \& O'Cass, 2012). This means 
that the effect of MO on FP will occur through the influence of SFMC in the analyzed context through the three dimensions. This research demonstrates that an SFMC is necessary to obtain FP. This type of performance has not been explored in previous sales capability studies (Krush et al., 2013, Siahtiri et al., 2014), and for this reason, it has a new theoretical implication for the marketing area.

Second, this study tests the interplay between MO and SFMC. Sales management aims to ensure sales force performance to achieve the objectives planned, according to a strategic orientation (Zoltners et al., 2008, Cravens et al., 1993). This management is responsible for the choices that are reflected in team behaviors (Baldauf et al., 2001). Thus, this study demonstrated that firms which make their managerial choices based on market generated information tend to perform better. That is, companies that acquire, disseminate, and coordinate market information across sales department using this information to influence SMFC to have superior FP.

Third, the findings of this study identify several contributions from SFMC to achieve FP (Homburg et al., 2015). In more detail, this study investigated the contribution of each dimension of SFMC in the proposed relationship. It was identified that the greatest contribution of the mediation effect is given by the CT dimension (H3c), followed by TM (H3b), with values which were very close. Thus, market-oriented companies understand the opportunities and threats of the environment, mainly the customers, and tend to pay more attention to how to manage salespeople on CT to achieve a better financial result. This result highlights the need to align human resources processes and sales management from market intelligence in order to meet the needs of consumers and thus achieve superior FP (Guenzi et al., 2016). Further, how to allocate the sales force in each customer segment is what will bring the company better financial results.

Also related to the mediating effects of the dimensions of the SFMC, it was verified that the variable SFS (H3a) exert less effect than the others. One interpretation is that structuring the sales force in firms can often include the size and organization of the team that will operate in different markets (Zoltners et al., 2008). Thus, this concept is more operational and depends on the company size. Further, this fact shows that how to allocate the sales force in each market segment is what will bring the company better financial results when compared to SFS. This dimension has a greater impact when analyzed separately (H2a).

\subsection{Managerial implication}

This study acknowledges that the role of MO on SFMC is crucial to obtain better results in B2B firms. It is also important to highlight the fact that developing and maintaining a market-oriented organizational culture is an essential prerequisite for high performance (Narver \& Slater, 1990), even in a highly competitive sector, such as ICT (BRASSCOM, 2016).

The software industry and service continuously develop new knowledge and technologies, as the product life cycle of this sector is shorter (Edison, Bin Ali, \& Torkar, 2013), so companies often work from the collaborative way (BRASSCOM, 2016). In addition, software solutions need to be integrated with each other, which leads to a certain standardization of products for final customers (Sánchez, 1999). This sharing of information and partners leaves companies in a similar way in relation to customer and competitor information. In this way, what can differentiate one company from another is the use of the information raised in the market and how these companies develop skills from them.

Regarding this context, this study suggests that marketing managers and sales managers should collaborate by exchanging information about the market and using this information strategically to target and position the sales force to obtain better financial results and to develop a competitive advantage (Guenzi \& Troilo, 2006; Siahtiri et al., 2014; Homburg et al., 2015).

By highlighting the impact of MO on firm's sales capabilities and consequently on FP, these findings allow to advance some implications for companies. First, companies should use market information to help in the structuring of the sales force, since it involves different decisions such as a number of salespeople and products assigned to each one (Rangaswamy et al., 1990). Second, sales managers should involve more marketing managers on how to manage sales team force to customer targeting, pay attention to the recruitment and training of talented individuals, which highlights the need for aligning human resources, market information, and sales management processes (Guenzi et al., 2016). Third, these studies highlight the importance of the engagement of marketing managers to support sales investments to achieve FP. 


\subsection{Limitations and Future Research}

This study presents the findings from an exploratory research made in the Brazilian B2B software sector. One research limitation is the application in a single sector of the economy, which does not allow to generalize these findings to other industries. Another limitation is the subjective form we measure the constructs, using latent constructs in this research. Future studies can apply this research in different segments, as well as insert personal sales capability to understand individual factors, as there is evidence that SFMC predates personal sales capability (Guenzi et al., 2016).

\section{References}

ABES - Associação Brasileira de Software. Mercado Brasileiro de Software - Panorama e Tendências 2015. São Paulo: 2015.

Baker, W. E., \& Sinkula, J. M. (1999). The synergistic effect of market orientation and learning orientation on organizational performance. Journal of the academy of marketing science, 27(4), 411-427.

Baldauf, A., Cravens, D. W., \& Piercy, N. F. (2001). Examining business strategy, sales management, and salesperson antecedents of sales organization effectiveness. Journal of Personal Selling \& Sales Management,21(2), 109-122.

BRASSCOM - Associação Brasileira de Empresas de Tecnologia da Informação e Comunicação. Brasil TIBPO Book 2013-2014. São Paulo: 2013.

BRASSCOM - Associação Brasileira de Empresas de Tecnologia da Informação e Comunicação. Brasil TIBPO Book 2015-2016. São Paulo: 2016.

Chang, W. J. (2014). Market orientation and business-to-business (B2B): a meta-analysis perspective. International Journal of Services Technology and Management, 20(1-3), 123-148.

Cohen, J. (1988). Statistical power analysis for the behavioral sciences. 2 ed. New York: Psychology Press.

Colton, D. A., Roth, M. S., \& Bearden, W. O. (2010). Drivers of international e-tail performance: the complexities of orientations and resources. Journal of International Marketing, 18(1), 1-22.

Cravens, D. W., Ingram, T. N., LaForge, R. W., \& Young, C. E. (1993). Behavior-based and outcome-based salesforce control systems. The Journal of Marketing, 47-59.

Cron, W. L., Baldauf, A., Leigh, T. W., \& Grossenbacher, S. (2014). The strategic role of the sales force: perceptions of senior sales executives. Journal of the Academy of Marketing Science, 42(5), 471-489.

Cruz-González, J., López-Sáez, P., Navas-López, J. E., \& Delgado-Verde, M. (2015). Open search strategies and firm performance: The different moderating role of technological environmental dynamism. Technovation, 35, 32-45.

Day, G. S. (1994). The capabilities of market-driven organizations. the Journal of Marketing, 37-52.

Deshpandé, R. (Ed.). (1999). Developing a market orientation. Sage.

Edison, H., Bin Ali, N., \& Torkar, R. (2013). Towards innovation measurement in the software industry. Journal of Systems and Software, 86(5), 1390-1407.

Fornell, C., \& Larcker, D. F. (1981). Structural equation models with unobservable variables and measurement error: Algebra and statistics.

Guenzi, P., Sajtos, L., \& Troilo, G. (2016). The dual mechanism of sales capabilities in influencing organizational performance. Journal of Business Research, 69(9), 3707-3713.

Guo, C., Wang, Y. J., Hao, A. W., \& Saran, A. (2018). Strategic positioning, timing of entry, and new product performance in business-to-business markets: do market-oriented firms make better decisions?. Journal of Business-to-Business Marketing, 1-14.

Hair Jr, J. F., Hult, G. T. M., Ringle, C., \& Sarstedt, M. (2014). A primer on partial least squares structural equation modeling (PLS-SEM). Sage Publications.

Hayes, A. F. (2013). Introduction to mediation, moderation, and conditional process analysis: A regressionbased approach. New York: Guilford Press.

Homburg, C., Vomberg, A., Enke, M., \& Grimm, P. H. (2015). The loss of the marketing department's influence: is it really happening? And why worry?.Journal of the Academy of Marketing Science, 43(1), 113.

Kirca, A. H., Jayachandran, S., \& Bearden, W. O. (2005). Market orientation: A meta-analytic review and assessment of its antecedents and impact on performance. Journal of marketing, 69(2), 24-41. 
Kohli, A. K., \& Jaworski, B. J. (1990). Market orientation: the construct, research propositions, and managerial implications. The Journal of Marketing, 1-18.

Krush, M. T., Agnihotri, R., Trainor, K. J., \& Nowlin, E. L. (2013). Enhancing organizational sensemaking: An examination of the interactive effects of sales capabilities and marketing dashboards. Industrial Marketing Management, 42(5), 824-835.

Kumar, V., Jones, E., Venkatesan, R., \& Leone, R. P. (2011). Is market orientation a source of sustainable competitive advantage or simply the cost of competing?. Journal of marketing, 75(1), 16-30.

Kumar, V., Sunder, S., \& Leone, R. P. (2014, September). Measuring and managing a salesperson's future value to the firm. American Marketing Association.

Liao, S. H., Chang, W. J., Wu, C. C., \& Katrichis, J. M. (2011). A survey of market orientation research (19952008). Industrial marketing management, 40(2), 301-310.

Lowry, P. B., \& Gaskin, J. (2014). Partial least squares (PLS) structural equation modeling (SEM) for building and testing behavioral causal theory: When to choose it and how to use it. IEEE transactions on professional communication, 57(2), 123-146.

Mamun, A. A., Mohiuddin, M.,Fazal, S. A., \& Ahmad, G. B. (2018). Effect of entrepreneurial and market orientation on consumer engagement and performance of manufacturing SMEs. Management Research Review, 41(1), 133-147.

Matear, S., Osborne, P., Garrett, T., \& Gray, B. J. (2002). How does market orientation contribute to service firm performance? An examination of alternative mechanisms. European journal of marketing, 36(9/10), 1058-1075.

Morgan, N. A. (2012). Marketing and business performance. Journal of the Academy of Marketing Science, 40(1), 102-119.

Morgan, N. A., Vorhies, D. W., \& Mason, C. H. (2009). Market orientation, marketing capabilities, and firm performance. Strategic Management Journal,30(8), 909-920.

Mohiuddin Babu, M., Liu, H., Jayawardhena, C., \& Dey, B. L. (2019). Impact of market orientation on firm's customer-based performance: the moderating role of employee orientation. Journal of Marketing Management, 35(7-8), 662-692.

Murray, J. Y., Gao, G. Y., \& Kotabe, M. (2011). Market orientation and performance of export ventures: the process through marketing capabilities and competitive advantages. Journal of the Academy of Marketing Science, 39(2), 252-269.

Narver, J. C., \& Slater, S. F. (1990). The effect of a market orientation on business profitability. The Jounnal of marketing, 20-35.

Ngo, L. V., \& O'Cass, A. (2012). In Search of Innovation and Customer-related Performance Superiority: The Role of Market Orientation, Marketing Capability, and Innovation Capability Interactions. Journal of Product Innovation Management, 29(5), 861-877.

Pekovic, S., \& Rolland, S. (2016). Customer orientation and firm's business performance: A moderated mediation model of environmental customer innovation and contextual factors. European Journal of Marketing, 50(12), 2162-2191.

Rangaswamy, A., Sinha, P. A., \& Zoltners, A. (1990). An integration model based approach for sales force structuring. Marketing Science, 9(4), 279-298

Rapp, A., Agnihotri, R., \& Baker, T. L. (2011). Conceptualizing salesperson competitive intelligence: An individual-level perspective. Journal of Personal Selling \& Sales Management, 31(2), 141-155.

Ringle, C. M., Da Silva, D., \& Bido, D. D. S. (2014). Modelagem de equações estruturais com utilização do SmartPLS. Revista Brasileira de Marketing, 13(2), 56-73.

Sánchez, L. M. P. (1999) Competition in the software industry: The interface between antitrust and intellectual property law. Communications \& Strategies, 35, 45.

Siahtiri, V., O'Cass, A., \& Ngo, L. V. (2014). Exploring the roles of marketing and selling capabilities in delivering critical customer centric performance and brand performance outcomes for B2B firms. Journal of Strategic Marketing,22(5), 379-395.

Shin, S., \& Damon Aiken, K. (2012). The mediating role of marketing capability: evidence from Korean companies. Asia Pacific Journal of Marketing and Logistics, 24(4), 658-677.

Smirnova, M., Naudé, P., Henneberg, S. C., Mouzas, S., \& Kouchtch, S. P. (2011). The impact of market orientation on the development of relational capabilities and performance outcomes: The case of Russian industrial firms. Industrial Marketing Management, 40(1), 44-53. 
Thornton, S. C., Henneberg, S. C., \& Naudé, P. (2015). An empirical investigation of network-oriented behaviors in business-to-business markets. Industrial Marketing Management, 49, 167-180.

Venkatraman, N. (1989). Strategic orientation of business enterprises: The construct, dimensionality, and measurement. Management science, 35(8), 942-962.

Venkatraman, N., \& Ramanujam, V. (1986). Measurement of business performance in strategy research: A comparison of approaches. Academy of management review, 11(4), 801-814.

Vorhies, D. W., \& Morgan, N. A. (2005). Benchmarking marketing capabilities for sustainable competitive advantage. Journal of marketing, 69(1), 80-94.

Wang, G., \& Miao, C. F. (2015). Effects of sales force market orientation on creativity, innovation implementation, and sales performance. Journal of Business Research, 68(11), 2374-2382.

Weitz, B. A., \& Bradford, K. D. (1999). Personal selling and sales management: A relationship marketing perspective. Journal of the academy of marketing science, 27(2), 241-254.

Zoltners, A. A., Sinha, P., \& Lorimer, S. E. (2008). Sales force effectiveness: A framework for researchers and practitioners. Journal of Personal Selling \& Sales Management, 28(2), 115-131. 